\title{
Psychological Education of Media Experts: Grounds for Strategy Selection
}

\author{
Olga F. Neskryabina* \\ Siberian Federal University \\ 79 Svobodny, Krasnoyarsk, 660041, Russia
}

Received 08.10.2014, received in revised form 21.12.2014, accepted 18.01.2015

\begin{abstract}
An increased interest in psychological knowledge that is typical of the media sphere defines the important role of psychological disciplines in the training process for media professionals. At that, the modern media environment is rich with psychological information of a low scientific level. Psychological texts circulating in the media space are marked by the strong influence of the mass culture.

The main characteristics of the masscult are: 1) entertainment; 2) low standards of scientificity; 3) eclecticism; 4) focus on the cognitive control of behaviour. These features connect with the intention of instrumentality of psychological concepts. This situation allows an analysis of the principles of selection of psychological knowledge to be included in the educational process.

Among these methodological grounds the most important are: the compliance with standards of scientificity, problematicity, systemacity, reflexivity. Following these grounds or principles allows overcoming the dependence of perception and thinking on general (for educational psychology) and specific cognitive sets. The general sets include: trust in the information organized in the form of a diagram, trust in typologies and classifications, quantitative estimations and terminological noveltydiagrams, numbers and words. In our opinion, the most important specific sets associated with the peculiarities of the profession are as follows:

- treatment of the audience as a faceless crowd that passively perceives information;

- identification of social information with the information spreading through the media;

- prevalence of the media text form over its content.
\end{abstract}

Keywords: media psychology, perception sets, systemacity, reflection, objectivity, problematicity.

Research area: philosophy.

\section{Problem}

Enriching education with psychological knowledge reflects the increased importance of a psychological paradigm in social analytics. This trend is typical of many specialities in the Humanities, but in particular it is inherent in the communicative disciplines. The article examines the current problems of professional training of specialists in the field of mass communications: journalists, experts in the field of advertising and public relations.

One of the most serious objectives of optimization of modern education is its contents. What are the grounds for information selection from the huge flow of knowledge circulating in the information space? (The "there is no extra

(c) Siberian Federal University. All rights reserved

* Corresponding author E-mail address: nescr@mail.ru 
knowledge" message does not work anymore due to the increased loads of information and the limited resources of a human brain).

Psychological discourse is a significant part of the information environment, in which the educational process of media experts is carried out. In this environment, an important place is taken by the "masscult psychology" represented by the available resources of the Internet, television, magazines and the "pop psychology" books.

The educational literature market is literally flooded with books of a dubious scientific value. A variety of publications' titles include the word "practical". This word contains a hint or a direct reference to the fact that the book can be a guide to managing people. Some unconfirmed "theories" enjoy undeserved popularity. Their success is due to the fact that they are similar to the practical recipes.

In our opinion, the main features of the masscult of psychological information in the field of education are: 1) a game principle, entertainment; 2) simplicity, low standards of scientificity; 3) eclecticism; 4) focus on the cognitive control of behavior (Neskryabina, Palieva: 2011, 6).

The relevance of psychological knowledge, its availability and quality result in the fact that the students acquire certain sets and stereotypes that have to be overcome in the training of such courses as "psychology" and "psychology of journalism".

Unconscious desire to see a respondent as an obedient object of influence determines which psychological concepts are popular among students, which ones are most memorable and are used when writing term and diploma papers. These popular ideological complexes include the following concepts: manipulation of consciousness, unconscious perception, virtual reality, clipping thinking, mythologism of mass consciousness, social constructivism and others.

One of the harmful sets is a belief that the student should not learn general psychology, but learn versions of psychology adapted to their profession. It seems more practical. But in reality, such practicality often becomes a simplified study of a human being. Of course, there are specific features of media psychology but the professional psychological culture of media experts is not limited by them. This does not mean that there is no need in specialized books. But such textbooks must either contain sturdy, without exceptions and simplifications, general part, or be an addition to the textbooks on general psychology (Neskryabina 2008: 5).

Selection of material for inclusion in the training courses can be expressed and analyzed as a system of interrelated criteria of the importance of psychological information. In our opinion, among these criteria the leading ones are: the standards of scientificity, systemacity, problematicity and reflexivity. These principles are interrelated and, in part, inter-determined, but at the same time can be described separately.

\section{Standards of scientificity}

In spite of doubt about the relevance of traditional standards of scientificity occurred in the academic and media discourses (which, in particular, is expressed in the popularity of "social constructivism" and "discourse analysis" (Jorgensen, 2008: 198), we believe that the classical rationality with its ideal of objective knowledge has not lost its significance. This opinion is due to the fundamental unity of the process of knowledge development, as well as the observed theoretical and methodological continuity of the scientific progress.

One of the most important reasons that a judgment belongs to the scientific discourse is a high level of its criticality. As for the opinions 
of psychologists that can be heard on television, it seems that they often lack criticality. This is especially noticeable when they judge personal qualities of some character based on the results of a brief observation of his behavior.

An insufficient level of criticality is manifested in the fact that some scientific problems are already claimed to be solved. In particular, this applies to the theory of the unconscious, the theory of memory, some theories of psychological types, etc. I think that the subject of the unconscious should be unfolded in all its complexity, because the understanding of the conditions and the possible influence on consciousness and behavior, in particular, media influence, depends on the interpretation of this modality of mentality. Today, the main source of the increase of knowledge in this area is neurobiology (Chernigovskaya, 2013: 10).

In order to master the psychological culture, a future media professional is not required to study brain functioning at the level of a single neuron structure and biochemical reactions occurring in a nerve cell. It is necessary and sufficient to know about the basic mechanisms of information perception and processing. Cognitive science should be presented by conclusions about the functioning of neural networks, the principles of perception, memory, thinking, and how this leads to its current state.

Criticality as a principle and a sign of the scientific discourse shows its second compulsory feature - intention to objectivity. In this case, we are referring to objectivity as overcoming temptation to indulge in wishful thinking. It is better for a media specialist to assume that the audience receives information passively, but the profit motive must yield to the need for objective knowledge.

Among specialists in the media theory, there are many statements on this issue. Here is what E.E. Pronina says about this situation: "Experts have successively passed from the idea of human helplessness before the omnipotence of the mass media to the notion of dependence of the mass media on the interests of the audience and independence of the recipient in the selection and use of information. The uncertainty in solving this matter is not reduced today and gets even worse, since with the development of the mass media, new and more vibrant evidence occur in favor of each of the mutually exclusive positions." The practice of the modern information campaigns provides grounds for the first point of view, and the development of the Internet communications for the second, states E.E. Pronina (Pronina, 2011: 106).

It should be added that the polarity of opinions reflects not only the characteristics of different media, but also individual differences of the information needs and abilities of the audience, because it (the audience) is not a homogeneous, faceless crowd. It can be assumed that with the removal of various spheres of public life from the personal experience of an individual, his dependence on the mass media covering the activities of these spheres increases. This statement is true provided that the respondent is interested, which is not always true. With the removal from the personal experience, dependence on the mass media can increase in a cognitive aspect and, on the contrary, can decline in a connotative way through the emotional detachment. Distancing turns out so that the respondent is not inclined to the critical perception, and, therefore, does not involve psychological defenses. As a result, information is perceived, but passively. Usually in such a psychological situation it has no noticeable emotional and motivational impact on the audience.

In a view of functioning processes of the mass media information there is a stereotype: the quality and quantity of the delivered information is equal to the quality and quantity of its impact 
on the audience. Here is an example of this stereotype: "Clipping culture dictating rapid change of plans,.. radically changes (has already changed practically) people's ability to take in information" (Novikova, 2013: 38). The notion of symmetry between the media space and the sphere of subjective perception is not consistent with the data of cognitive science. The likelihood ratio, to some extent, exists at the stage of the incentive processing, but disappears at the stage of response.

\section{Systemacity of mind}

\section{and systemic methodology of its research}

One of the verifying rules that increase the probability of the truth of a certain hypothesis is its embeddedness in the system of theoretical knowledge. This methodological rule supplements the principle of experimental verification, since it is hard to empirically substantiate many of the realities associated with the world of subjectivity, at least at the present level of development of mental visualization methods. For example, the classification of C.G. Jung that is popular in the academic literature and that allocates psychological types by the criterion of predominance of one of the subsystems of the psyche, is insufficiently substantiated in an empirical way. A verifying ground for this typology could be its embeddedness in the system of the psycho-physiological theory. But there is no such systemic confirmation for it, so the inclusion of this segment in the body of actual psychological knowledge is hardly justified. The issue of the practical value of the subthreshold exposure techniques and some other features of perception, as well as numerous typologies of personality and the corresponding test methods is solved in the same way.

Systemacity deficit manifests itself in an eclectic mixture of different psychological approaches. Thus, behavioral explanations of human behavior in the media sphere without sufficient justification are complemented with Freudian motifs (Pronina, 2011). The presentation of psychological concepts of Freud, Jung, Erikson and others without their correlation with current scientific knowledge is widespread. We should mention that we are not talking about how to exclude some names or concepts. The thing is that the status of these concepts in the system of scientific knowledge would be determined as accurately as possible.

Contemporary psychological knowledge is still not well integrated and, therefore, it is necessary to designate the points of paradigmatic transitions and strict methodological reflection.

\section{Problematicity as relevance and hypotheticality}

One of the major methodological rules of selection and presentation of psychological information is its problematicity. It is present in two ways: firstly, as relevance, and secondly, as hypotheticality. In the first variant problematicity serves as a basis for introduction of information into the educational content, in the second - it requires not to pass unresolved scientific problems for the solved ones.

Presentation manner of psychological information in the mass media is often marked by the desire to give a categorical judgment. In one of the November programmes on the OTR channel devoted to mental illnesses of brilliant people, the authors of the programme make diagnoses for outstanding people that are not consistent with the facts of their biographies and are not backed by expert opinions.

Excessive certainty together with a sensational presentation of information is present in some materials on the achievements of neuroscience. So in the article "Who is afraid of neuroeconomics? Nerve cells make all the decisions for us" the acceptance of the fact that 
the studies "are only the first steps" is combined with certain, but not hypothetical, judgments about the causes of human economic behavior (Konstantinov, 2013: 58).

One of the topical problems remains the problem of the unconscious in the mind's structure and its role in the media psychology. In the way of how this phenomenon is interpreted there are unverifiable stereotypical views and estimates that acquired the status of a scientific tradition due to their stability. Thus, one of the papers states that "...both social mythologems and artificial stereotypes can exist only in the unconscious sphere, beyond rational comprehension" (Kovalev et al., 2013: 23). In this kind of judgments the unconscious is equated with the incomprehensible and unexplained, which makes its ontological status problematic. The answer to the question of how the unconscious exists in the mind depends on how we will be presenting its circulation in the media space. We must honestly admit that our knowledge of these processes is still hypothetical. Firstly, we should raise the question: what is the unconscious? Cognition of a stereotype, its content or its property, its definiteness as a stereotype or a myth, if the case is a myth. It seems that the unconscious is a mythological nature of the myth, but not its narrative. The presence of the real and unreal in the structure of the myth does not reach the level of realization, and the reasons for its vitality or its mental functions are not understood as well.

Apparently, in order to explicate the unconscious, it is necessary to analyze not the "conscious-unconscious" pair, but a triad: "ignorance-unconscious-conscious". We do not see the difference from the inside of the subject, where we are dealing with a lack of information (ignorance) and where this information does not reach the level of awareness. Until we have a clear understanding of these connections and transitions, the process of transfer of the unconscious and the very idea of the possibility of its transfer through the media channels, the topic should maintain the status of the problematic knowledge.

\section{Reflexivity}

The necessity of reflexivity as criticality was already mentioned above. However, there are some aspects in this problem that require a separate discussion. Let us mark out some important directions of the study.

Reflexivity in terms of this article involves the work on the realization of motivational, emotional and cognitive sets that contain the possibility of subjective perception of psychological information. There are two types: 1 - general sets - those that always occur in the learning process, and 2 - specific sets. Their occurrence is connected with a professional orientation, with age characteristics of students, with belonging to a particular generation and socio-cultural identity.

Awareness of the general features of perception of educational information involves consideration of natural cognitive sets. They can be called natural because they occur without any effort, since they express the features of mental processes. These sets include, for example, trust in the information organized in the form of a diagram, trust in typologies and classifications, quantitative estimations and terminological novelty - diagrams, numbers and words. It is important not to oppose these features, but to work with them making them more conscious, contextual and correlated to specific cognitive goals.

We believe that the most important specific sets associated with the peculiarities of the profession are as follows:

- Treatment of the audience as a faceless crowd that passively perceives information. The antidote to that is 
studying the differences between a crowd, mass and a group. In teaching we should pay more attention to the study of psychology of individual differences.

- Identification of social information with information spreading through the media. In the study of psychology in order to overcome this incompleteness of understanding it is necessary to focus on the value of people's everyday experience, to analyze the increased possibilities of self-perception and understanding of reality, which is associated with the growth of education of the population and the use of new information technologies.

- Prevalence of the media text form over its content. Compared with scientific texts media texts are much more focused on the connotative effect, which is a socio-organizing function of journalism. This feature of the media creative work and its teaching makes us believe that the effectiveness of the impact of media information depends on the form and methods of its presentation to a greater extent than on the content.

It is not desirable to cultivate the current set because if a journalist's talent is associated with how skillfully he uses means of expression, it means blurring of boundaries between journalistic and artistic creation, and between the spheres of the media space - journalism, PR and advertising.

\section{Conclusion}

Concluding the analysis of the problem stated in the title, it should be noted that psychologizing education of the media experts does not mean the spatio-temporal expansion in the educational process, but it manifests itself by the increase of importance of psychological knowledge. This result can be achieved by criticality of selection of the psychological information and the depth of its presentation.

It is necessary to overcome contradictions between the declared principles and educational strategies that are implemented in the available educational resources. The scientific educational discourse proclaims systemacity, but in the media space the dominant features are the mosaic structure and fragmentation of psychological content. In theory there is a principle of activity of information perception, but in practice training of the manipulation methods prevails. It is necessary to focus on the activity of information perception to overcome the effect of the interest of the future media professionals in the image of the audience as a passive object of action.

In teaching psychology we should avoid the temptation of simplicity, entertainment and simplified practicality. Teaching strategies do not have to follow the imperfect social practice, they should be focused on the high standards of scientificity.

\section{References}

1. Chernigovskaya, T.V. Cheshirskaya ulybka kota Shredingera: yazyk i soznaniye [The smile of the Schrodinger's Cheshire cat: language and mind]. T.V. Chernigovskaya. Moscow: Slavic culture Languages, 2013.

2. Jorgensen, M.W. Discourse Analysis as Theory and Method. M.W. Jorgensen, L. Phillips. Translation from English. $2^{\text {nd }}$ edition. "Center for the Humanities" Publishing House, 2008. 
3. Kovalev V.V., Sazhina L.V., Scryabina N.Yu., Kormilchenko V.V., Ivanova N.B. Kommunikativnye problemy upravleniya obshchestvennymi otnosheniyami [Communicative problems of managing public relations]. Moscow: Vuzovskaya kniga, 2013.

4. Konstantinov A. Kto boitsya neyroekonomiki? [Who is afraid of neuroeconomics?] RR. 2013. No. 18-19 (296-297).

5. Neskryabina, O.F. Mediapsikhologiya and mediaetika [Media psychology and media ethics]. Krasnoyarsk: SibLI, 2008.

6. Neskryabina, O.F. Mediapsikhologiya and mediaetika: [Media psychology and media ethics] Textbook: in 2 parts. Part 1. Mediapsikhologiya [Media Psychology]. Krasnoyarsk: SibFU, 2011.

7. Novikova, A.A. Televizionnaya realnost: ekrannaya interpretatsiya deistvitelnosti [Television Reality: on-screen interpretation of reality]. Moscow: Publishing House of the Higher School of Economics, 2013.

8. Pronina, E.E. Kategorii mediapsikhologii: fakty, fenomeny, fantomy. [Media psychology categories: facts, phenomena, phantoms] Part of "Man as a subject and object of media psychology. MSU. Department of Journalism. Moscow, 2011. P.106-150. P.106. Http://rpo.rf/library/pdf/person. pdf

\title{
Психологическое образование медиаспециалистов: основания выбора стратегии
}

\author{
О.Ф. Нескрябина \\ Сибирский федеральный университет \\ Россия, 660041, Красноярск, пр. Свободныій, 79
}

\begin{abstract}
Повышенный интерес к психологическому знанию, присутствующий в медиасфере, определяет важную роль психологических дисииплин в системе подготовки медиаспециалистов. При этом современная медиасреда насыщена психологической информацией невысокого научного уровня. Психологические тексты, обращающиеся в пространстве медиа, отмечены сильным влиянием массовой культуры.

Признаками масскультности являются: 1) развлекательность; 2) низкие стандарть научности; 3) эклектизм; 4) установка на когнитивный контроль поведения. Эти черты соединяются с интеничиеи инструментальности психологических конщептов. Данная ситуация делает нетривиальным анализ принџипов отбора психологического знания для включения в образовательный процесс.

Среди таких методологических оснований наиболее важными являются: соответствие стандартам научности, проблемность, системность, рефлексивность. Следование данным основаниям или принципам позволяет преодолевать зависимость восприятия и мышления от общих для психологии образования и специфических когнитивных установок. К общим относятся: доверие к информачии, организованной в виде схемы, доверие к типологиям и классификациям, количественным оценкам и терминологической новизне - «магии» схемы, числа и слова. Наиболее важными специфичными установками, связанными с особенностями профессии, наш взгляд, являются:

- отномение $\kappa$ аудитории как $\kappa$ безликой массе, пассивно воспринимающей информацию;
\end{abstract}


- отождествление сочиальной информации с информащией, распространяющейся по каналам СМИ;

- представление о преобладании формы медиатекста над его содержанием.

Ключевые слова: медиапсихологии, установки восприятия, системность, рефлексия, объективность, проблемность.

Научная специальность: 09.00.00 - философские науки. 